УДК: 7.033.2(497), 7.033.2(471)

ББК: $85.14,85.143(2)$

A43

DOI: $10.18688 /$ aa199-2-30

M. Tomić Djurić

\title{
Monumental Painting in the Mrnjavčević State and Late Medieval Novgorod: Parallels in Program and Iconography'
}

For many years scholars have tried to explore the relationship between Serbian and Novgorodian painting from the Late Palaiologan period and to retrace the roots that led to multiple ties between the artistic achievements of late medieval churches in the Balkans and in Russia [17, pp. $85-90 ; 18 ; 23$, pp. $138-140 ; 3 ; 29 ; 30 ; 33 ; 36 ; 41]$. The present paper aims to examine iconographic and programmatic parallels between the pictorial ensembles of the churches from two distant regions - the Mrnjavčević State in the Balkans (1365-1395) (Fig. 1) and Novgorod of the late $14^{\text {th }}$ and $15^{\text {th }}$ Centuries.

\section{Fresco Decoration of the Domes}

Programs in the domes of the most important endowments of the Mrnjavčević family members feature very similar solutions. The oldest and most notable among them is the church of St. Demetrios at Sušica near Skopje (Markov Manastir). The construction of the katholikon between 1365/1366 and 1371 was directly associated with the political rise and the newly acquired royal dignity of its founder [13], Vukašin Mrnjavčević. The church was adorned with frescoes in 1376/1377, owing to the efforts of Vukašin's son, King Marko [27; 5; 10, pp. 74-75]. Shortly thereafter, in his capital of Prilep, around 1380 King Marko commissioned a re-frescoing of St. Demetrios, a church dating from the last decade of the $13^{\text {th }}$ century [6, p. 87; 16, pp. 206-207]. Not far from Skopje, on the banks of the River Treska, a territory under his domain, Marko's younger brother, the kraljević Andrejaš, in 1388/1389 built and decorated with frescoes a church he dedicated to St. Andrew. Like the dome of the church of St. Demetrios in Prilep, the painting of the last great medieval monument in these parts was also entrusted to the workshop of the metropolitan Jovan Zographos [9; 32].

In contrast to most $14^{\text {th }}$-century Serbian churches, in which, as a rule, the medallion of Christ Pantokrator in the dome is surrounded by a depiction of the Celestial Liturgy [37], in the domes of these three churches the Saviour appears surrounded by different groups of heavenly creatures. At Markov Manastir Christ is encircled with eight standing figures of asomatoi, four archangels and four angels dressed in regal attire, with orbs and scepters in

The paper is a result of research on the project Medieval Heritage of the Balkans: Institutions and Culture (177003) supported by the Ministry of Education, Science and Technological Development of Serbia. Four archangels and four six-winged creatures - a pair of seraphim and a pair of cherubim - were painted. The archangels are wearing chitons and cloaks. 


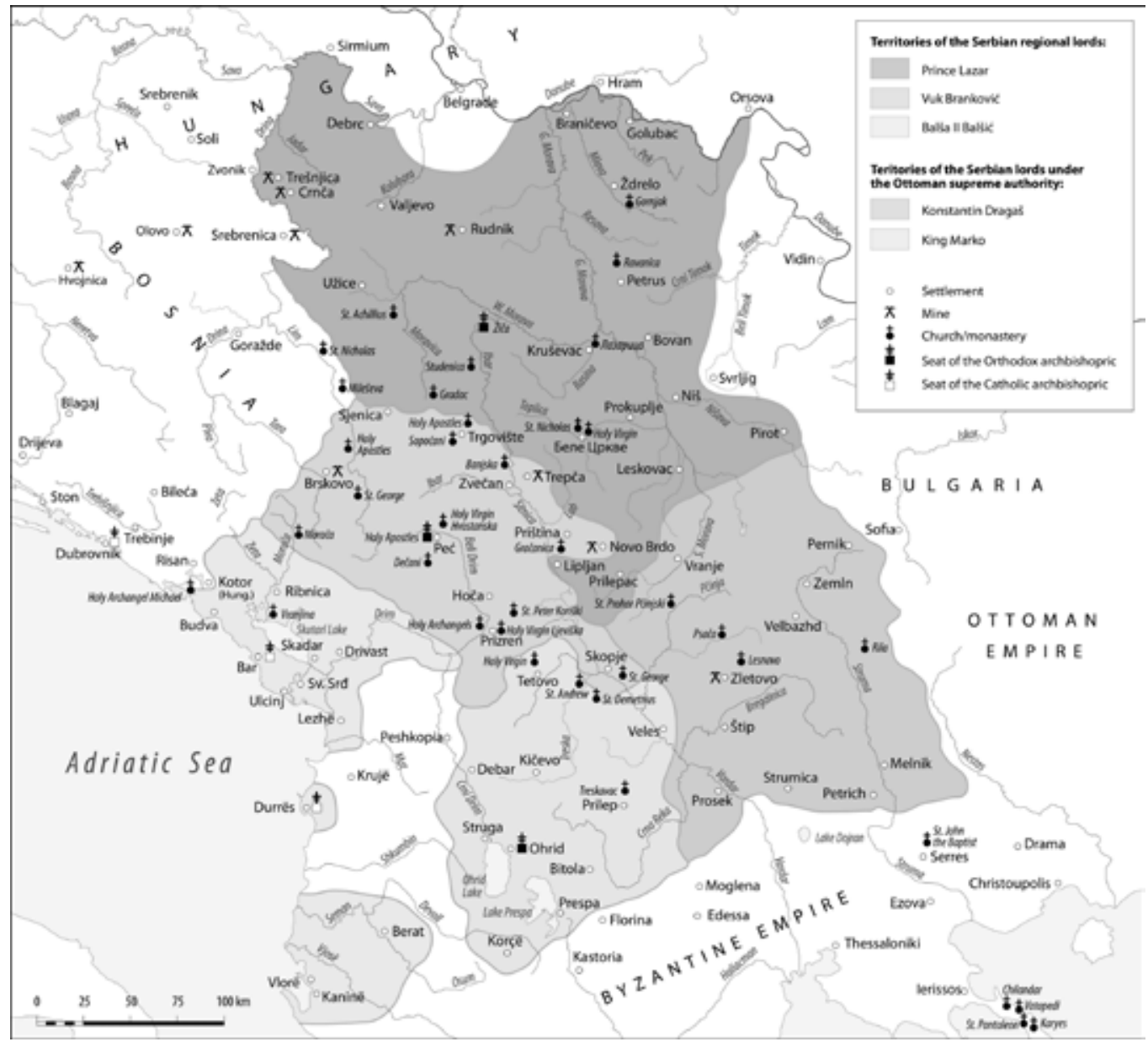

Fig. 1. Map of Serbia in the time of the regional lords, c. 1385 (after: Byzantine Heritage and Serbian Art II, Belgrade, 2016)

their hands [45, pp. 12-13] (Ill. 60). The dimensions of the drum at St. Demetrios in Prilep required a more summarized iconographical depiction of the asomatoi and hence seven medallions with busts of angels dressed in chitons and hematia and holding orbs in their hands surround the Pantokrator [6, p. 87, fig. 2]. The third iconographical solution was left by the painting workshop led by painter Jovan. Like the painters of the Novgorod churches, they also painted four angels, two seraphim and two cherubim, around the now missing image of the Pantokrator in the centre of the dome [32, fig. 3].

The structure of the angelic groups that surround the Pantokrator in Late Byzantine churches varies [31]. Standing figures of archangels dressed in chitons with himations or in regal attire were rarely included in the programmatic concepts in the domes of $14^{\text {th }}$-century Eastern Christian churches. Similar arrangements of standing angels and archangels in regal costumes can also be found in the Balkans - in the Church of St. Catherine in Thessaloniki (between 1315 and 1325) [44] and probably also in the Church of St. John the Theologian in 


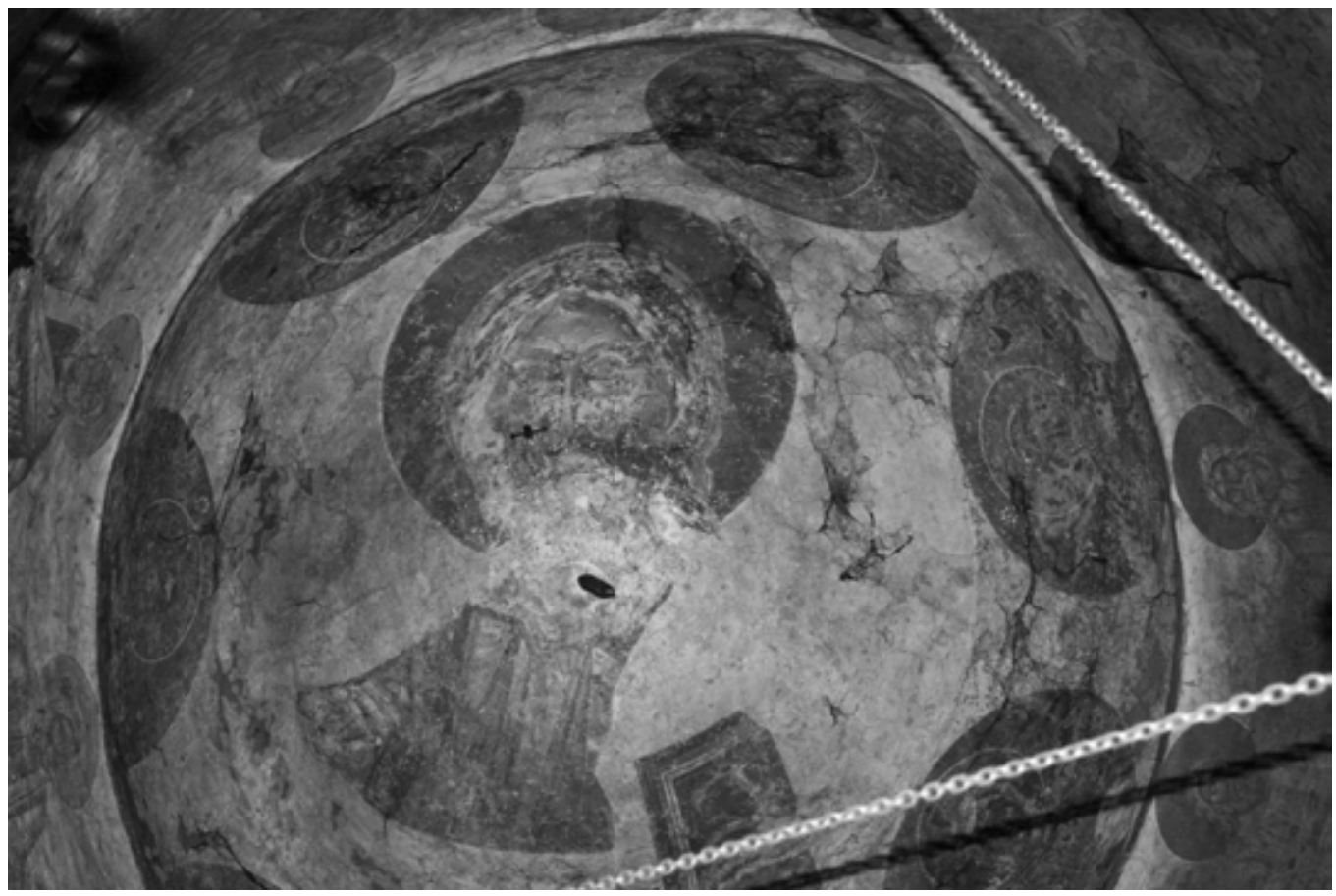

Fig. 2. Prilep, The Church of St. Demetrios, c. 1380, frescoes in the dome. Photo by T. Starodubcev

Zemen (c. 1360) [25, p. 24; 4, p. 169], where extensive damage precludes definite identification. However, the closest parallels for the iconographic and compositional formula adopted at Markov Manastir and Andrejaš are found in the Novgorodian iconographic tradition. The four standing figures of archangels and four six-winged creatures (seraphim and cherubim) represented in the church of St. Sophia in Novgorod (1109), were repeated in six Novgorod churches of the second half of the $14^{\text {th }}$ century: the Assumption in the Volotovo Field (1363) [47, pp. 114-116, figs. 3, 5, 7, 9; 11, pp. 217-233, fig. 4] $]^{2}$, the Saviour-Transfiguration in Iliina Street (1378) [20, p. 22, figs. 111, 113, 114] $]^{3}$, St. Theodore Stratelates 'on the Spring' (c. 1378) [42, pp. 48-55, figs. 10-15] $]^{4}$, the Holy Saviour in Kovaliovo (1380) [2, pp. 25-31] , the Nativity on the Red Field (last decade of the $14^{\text {th }}$ century) $[17$, p. 90; 42] and Archangel Michael Church in Skovorodsky Monastery (end of the $14^{\text {th }}$ - beginning of the $15^{\text {th }}$ century) ${ }^{6}$ $[19 ; 22 ; 34 ; 35]^{7}$. In Novgorod, the same thematic concept of the dome remained in use dur-

2 Four archangels and four six-winged creatures - a pair of seraphim and a pair of cherubim - were painted. The archangels are wearing chitons and cloaks.

3 Four archangels in regal attire with a loros were painted, as well as four six-winged creatures - a pair of seraphim and a pair of cherubim.

$4 \quad$ Four archangels in regal attire with a loros were painted, as well as four six-winged creatures - a pair of seraphim and a pair of cherubim.

Besides archangels and cherubim, tetramorphs were also shown.

I am indebted to Tatiana Tsarevskaya for having brought the example from this church to my attention.

Pantokrator is encircled with the four standing figures of archangels [31, p. 202]. 


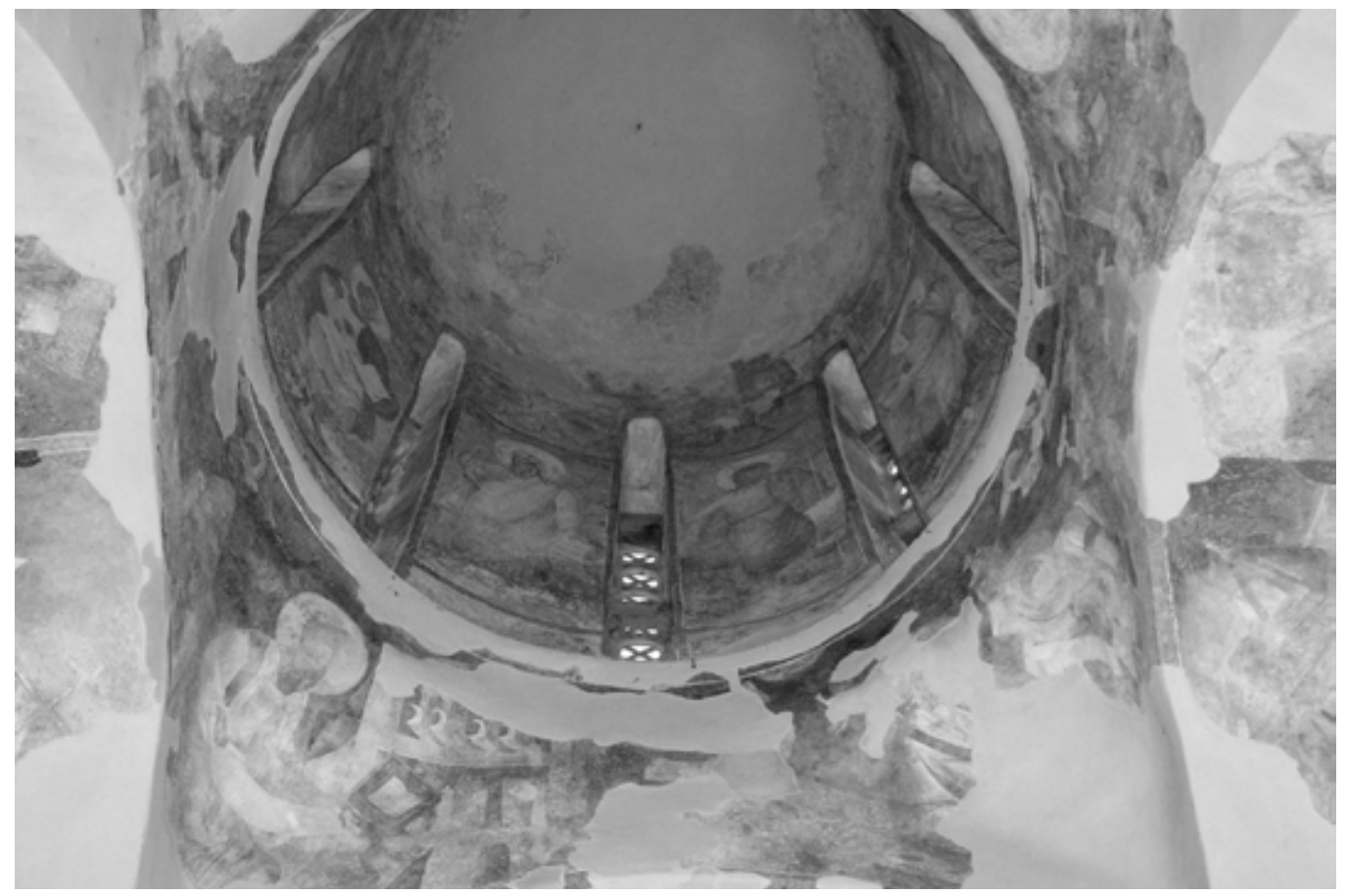

Fig. 3. The Church of St. Andrew at Treska, 1388/1389, frescoes in the dome

ing the following century, as evidenced by the church of St. Simeon the God-Receiver at the Zverin monastery (1467) [7; 14].

Extant inscriptions accompanying archangel representations in these churches reveal an interesting detail. Along with the two main archangels, Michael and Gabriel, handbooks used by painters in Serbia and Russia also included the names of apocryphal archangels (Uriel, Raphael; Markov manastir, Volotovo). Some of them are very rarely depicted in art, such as Barachiel and Jegudiel (St. Theodore Stratelates 'on the Spring').

Illustrations of prophetic visions of the Pantokrator surrounded by the Heavenly host received a more complex iconographical concept as early as the Middle Byzantine period [27, pp. 113-134]. Depictions of archangels in regal attire were used to convey the idea of the Lord of Hosts, who rules the entire heavenly and earthly kingdom [12, p. 451]. This image of the celestial hierarchy, imbued with the teachings of Pseudo-Dionysios the Areopagite, was seen as parallel to the hierarchical organization of the Byzantine society. Iconodulist theological works established the notion of archangels as the witnesses of the Incarnation, and hence their placement beside the Pantokrator image served to affirm the divine and human nature of Christ Philanthropos [26, cols. 396A-397B]. The depiction of angelic orders around the Pantokrator also had a direct liturgical meaning. The selection of angels and archangels was based on the text of the first Eucharistic prayer in the Divine Liturgy of St. John Chrysostom, which mentions 'ranks and hosts of angels and archangels'. The ancient liturgy mentioned the archangels Michael, Gabriel, Uriel 
and Raphael, while the Liturgies of St. Basil the Great and St. John Chrysostom name only Michael and Gabriel [1, p. 322].

The painters in the Mrnjavčević State used iconographical language to offer a clear visual representation of the celestial hierarchy of angels. The same can be said of Theophanes the Greek and his Greek and Russian understudies. Depicted exclusively from the front, with their wings down, unmoving but with their legs spread slightly apart, angels and archangels leave the impression of standing celestial guard around the Throne of God, glorifying the Pantokrator.

It seems entirely reasonable to conclude that the dome solutions in Novgorodian churches follow the older programmatic and iconographic tradition implemented at the Church of St. Sophia in Novgorod in the early $12^{\text {th }}$ century. The choice of this theme for the dome scene at Markov Manastir is more complex. However, it can be easily explained by the fact that the lower altar zone features a distinctive visual representation of the teaching of the unity of heavenly and earthly liturgy, united in the ministration of Jesus Christ as the Great High Priest, leading to the omission of the usual representation of the Divine Liturgy in the dome [38, pp. 129-133, fig. 4]. A growing interest in the celestial hierarchy, as attested in the visual arts of the Slavic world in this period clearly represents the adoption of Byzantine iconographic formulae. At this time, more specifically during the last three decades of the $14^{\text {th }}$ century and beyond in the Serbian and Russian milieu can be noticed a renewed engagement with the works of Pseudo-Dionysios, an author who worked in the late $5^{\text {th }}$ century and whose identity throughout the entire medieval period remained hidden behind the name of the famous bishop of Athens and disciple of Paul the Apostle. The Corpus Areopagiticum was translated into Old Serbian by the monk Isaiah (Inok Isaija) on Mount Athos around 1371 [28, pp. 154-158; 39, p. 51; 40; 8]. His entire opus comprises four treatises - On the Celestial Hierarchy, On the Ecclestiastical Hierarchy, On the Divine Names and On the Mystical Theology - accompanied by the interpretations of Maximus the Confessor (580-662). The translation was commissioned by Theodosios, Metropolitan of Serres, an advisor to Despot Uglješa, brother 
of Vukašin Mrnjavčević, who ruled the region of Serres. This Serbian translation of the corpus (National Library of Russia in Saint-Petersburg, Giljferding Collection, Ms. 46) ${ }^{8}$ was the first comprehensive translation of the opus of Pseudo-Dionysius the Areopagite among the Slavs: that's why it served as the protograph for a large number of Bulgarian and Russian copies. Pseudo-Dionysius's writings could not have influenced the appearance of the programmatic solutions discussed here in Serbian and Russian churches in the $14^{\text {th }}$ century or the manner of representing angels. This text however provided the grounds for more in-depth notions of the asomatoi and the celestial hierarchy. Thus the angels and archangels depicted in the dome of Markov Manastir belong to the lowest order in the celestial hierarchy of angels, in line with the concept of Pseudo-Dionysius the Areopagite. Their role is reflected in fulfilling God's orders and mediating between the heavenly and earthly world. The composition of the celestial hierarchy in Novgorodian churches includes the higher order of celestial beings - seraphim, cherubim and in some cases even tetramorphs.

Finally, there is another noteworthy similarity in the programmatic solutions of the dome images in the aforementioned churches. The domes of the Saviour-Transfiguration in Iliina Street and St. Theodore Stratelates at the Spring feature inscriptions quoting Psalm 101:20-22 [42, p. 50], the same verses that also appear in the dome at Markov Manastir [45, pp. 14-15]. Although it was inscribed in the domes of Byzantine and Serbian churches frequently enough, in these examples this Psalm has an obvious programmatic value. This is indicated by the quote which underlines Christ's sovereign place in the celestial hierarchy, God's mercy and the glorification offered by the entire mankind.

\section{Painted menologia}

The second part of the paper is concerned with the painted menologia at Markov Manastir [24] (Ill. 61) and in the church of St. Simeon the God-Receiver at the Zverin monastery (1467) [7; 46] (Ill. 62). At Markov Manastir, the menologion cycle covers the altar and the naos. It is shown in its abridged form and spans only three and a half months - from September $1^{\text {st }}$ to December $14^{\text {th }}$. Two peculiar features distinguish this calendar from other surviving $14^{\text {th }}$-century examples. First, instead of scenes depicting the death of martyrs, all saints and feast compositions are shown as busts. Secondly, the images of the saints are placed in calyces of multicoloured flowers arranged in two rows. They are connected by a flowering vine forming a wreath. At the Church of St. Simeon the God-Receiver in Novgorod, the full annual calendar makes up the bulk of the thematic program. Frontal half-length figures representing 366 saints are arranged along the walls, inner sides of arches and the pillars from below the dome to the lowest zone of frescoes?. Ensembles in this exceptional example of an illustrated menologion are separated by horizontal decorative ribbons filled in with leaved vines with multicoloured flowers.

There are obvious differences between the two cycles in terms of their date, iconographic and textual sources, spatial layout, and the number of images included. It can be argued, nonetheless,

\footnotetext{
$8 \quad$ A more recent edition of the Corpus Areopagiticum translated by the monk Isaiah in 1371 [8].

9 Complete content of the menologion with the disposition of figures, drawings, following photo documentation and bibliography in the church of St. Simeon the God-Receiver at the Zverin monastery in Novgorod was published by Natalia Vvedenskaya [46].
} 
that both cycles follow the same pictorial logic. They both belong to the same tradition of calendrical illustration in Eastern Christian art, which is characterized by the reduction of the visual programme to only one type of image - the portrait of the commemorated saint. The group in question is very small and includes a limited number of examples of icon-painting and monumental art. The absence of the scenes depicting martyr deaths is the main characteristic of the group of calendar icons from the Monastery of St. Catherine on Mount Sinai, created sometime between the late $11^{\text {th }}$ and the end of the $12^{\text {th }}$ century. The saints whose lives did not end in an act of martyrdom were represented in this way. Standing figures of saints taken out of their hagiographical context are also found in later menologion illustrations, albeit rather sporadically. For the matter at hand it is important to note several other Russian calendrical icons from the $16^{\text {th }}$ century, such as: icons for January - March (State Russian Museum in Saint Petersburg, Hermitage Museum); icons for March — July (Kostroma Museum, Ipatiev Monastery); menologion icons from the museum in Recklinghausen (Germany). An analogy from the field of monumental art is found in the calendar painted in the Church of St. Anthony at the Vrontissi Monastery in Crete (1420-1430). Much younger menologia from the period of Ottoman rule in the Balkans include the cycle from the Serbian church of St. Nicholas in Pelinovo (second decade of the $18^{\text {th }}$ century).

Floral decoration is another important compositional and iconographic element of the two calendars under discussion [15, pp. 297-301]. Leaved vines and flowers intertwined around the busts or figures of saints became constant features of the iconographic themes representing genealogies, prophets and evangelists (Tree of Jesse, Nemanjić family tree, prophets, Christ the True Vine). The fundamental meaning of the iconographical and literary motif of a wreath belongs to the great Christian topic of martyrdom. The distinctive symbol of eternal bliss in the kingdom of heaven represents the ultimate reward granted to the greatest warriors and martyrs of the faith. The symbolism of leaves and flowers is part of the rhetorical image of heaven and the depictions of heaven in miniature painting. Therefore, it can arguably be concluded that the wreath of multicoloured flowers represents a carefully selected element intended to contribute, through the attractive meaning of its iconography, to the main idea behind both cycles - the 'wreath' of the church year filled with saints in their heavenly afterlife.

\section{$* * *$}

Finally, the similarities revealed in this comparative analysis of the iconographical and programmatic solutions at Markov Manastir and a group of Novgorodian churches of the late $14^{\text {th }}$ and $15^{\text {th }}$ centuries warrant a reconsideration of the ties between late $14^{\text {th }}$-century Russian and South Slavic art and the origin of foreign painters who worked in the far North. The painters commissioned by King Marko and his Greek and Russian contemporaries in Novgorod were well-educated and talented artists. Analogies between the frescoes of Markov Manastir, the Church of St. Demetrios in Prilep or Andreaš and the works of Theophanes the Greek and other masters whose names have been lost to us indicate that in these very distant areas worked painters who shared similar esthetic principles. Spiritual inspiration for art creation also had a similar development in both milieus, as I have tried to elucidate in this short contribution. The parallelism between the ideas that underpin the thematic programmes of these churches supports such a conclusion. 


\section{References}

1. Brightman F. E. Liturgies, Eastern and Western, vol. 1, Eastern Liturgies. Oxford, Clarendon Press Publ., 1896. 568 p. (reprinted 1965).

2. Dmitrieva S. O. Freski khrama Spasa na Kovaliove $v$ Novgorode 1380 goda (Frescoes of the Church of the Savior on Kovaliovo in Novgorod, 1380). Moscow, Galart Publ., 2011. 272 p. (in Russian).

3. Dmitrieva S. The Depictions of Warrior Saints in Frescoes of 1380 at the Church of the Holy Saviour in Kovaliovo. Whether Balkan Masters Painted the Novgorod Church? Zograf, 2009, vol. 33, pp. 121-134.

4. Djorđević I. M. Zidno slikarstvo srpske vlastele u doba Nemanjića (The Wall Paintings of the Serbian Nobility of the Nemanide Era). Beograd, Filozofski fakultet Publ., 1994. 309 p. (in Serbian).

5. Djurić V. J. Markov manastir - Ohrid. Zbornik Matice Srpske za Likovne Umetnosti, 1972, vol. 8, pp. 131-160 (in Serbian).

6. Djurić V. J. Vizantijske freske u Jugoslaviji (Byzantine Frescoes in Yugoslavia). Beograd, Jugoslavija Publ., 1974. 233 p. (in Serbian).

7. Gerasimov N. N. Frescoes of the Church of Symeon the God Receiver in Novgorod Zverin Monastery. Pamiiatniki kul'tury. Novye otkrytiia. Ezhegodnik 1978 (Monuments of Culture. New Discoveries. Annual 1978). Leningrad, Nauka, Leningradskoe otdelenie Publ., 1979, pp. 242-266 (in Russian).

8. Goltz H.; Harney J.; Prokhorov G. M.; Fahl S.; Fahl D. (eds.). Das Corpus des Dionysios Areiopagites in der slavischen Übersetzung von Starec Isaija (14. Jahrhundert), 5 vols. Freiburg i. Br.: Weiher; St. Petersburg, Russische Nationalbibliothek Publ., 2010-2013 (in Old Slavonic).

9. Grozdanov C. Metropolitan Jovan the Painter and the Bishop Grigorij - Hierarchs of the Bishopric of Pelagonia and Prilep. Živopisot na Ohridskata arhiepiskopija. Studii (Frescoes of the Ohrid Archbishopric. Studies). Skopje, Makedonska akademija na naukite i umetnostite Publ., 2007, pp. 233-246 (in Macedonian).

10. Grozdanov C.; Subotić G. The Church of St. George in Rečica near Ohrid. Zograf, 1981, vol. 12, pp. 62-75.

11. Ivannikova A. P. The Iconographic Program for the Painting of the Dome of the Church of the Assumption on the Volotovo Field in Novgorod. Seminarium Bulkinianum II: Collection of articles. St. Petersburg, St. Petersburg University Press Publ., 2007, pp. 217-233 (in Russian).

12. Jolivet Lévy C. Note sur la représentation des archanges en costume impérial dans l'iconographie byzantine. Cahiers archéologiques, 1998, vol. 46, pp. 121-128 (in French).

13. Kasapova E. Arhitekturata na crkvata Sv. Dimitrija - Markov Manastir (The Architecture of the Church of St. Demetrios - Markov Manastir). Skopje, Kalamus Publ., 2012. 408 p. (in Macedonian).

14. Kolpakova G. S. On the Murals of the St. Simeon the God-Receiver Church in Novgorod. Drevnerusskoe iskusstvo. Monumental'naia zhivopis' XI-XVII vv. (Old Russian Art. Monumental Painting of the $11^{\text {th }}-17^{\text {th }}$ Centuries). Moscow, Nauka Publ., 1980, pp. 297-304 (in Russian).

15. Kovaleva V. M. On the Question of Changing the Original Colors of Some Monuments with Fresco Painting of the $12^{\text {th }}-15^{\text {th }}$ Centuries. Drevnii Novgorod. Istoriia, iskusstvo, archeologiia. Novye issledovaniia (The Old Novgorod. History, Art, Archaeology. New Researches). Moscow, Izobrazitelnoe iskusstvo Publ., 1983, pp. 297-313 (in Russian).

16. Korunovski S.; Dimitrova E. Vizantiska Makedonija (Byzantine Macedonia). Skopje, Prosvetno delo Publ., 2006. 279 p. (in Macedonian).

17. Lazarev V. N. Iskusstvo Novgoroda (The Art of Novgorod). Moscow; Leningrad, Iskusstvo Publ., 1947. 360 p. (in Russian).

18. Lazarev V. N. The Wall-Paintings of Kovaliovo and the Problem of South-Slavic Connections in the Russian Painting of the $14^{\text {th }}$ Century. Lazarev V. N. Russkaia srednevekovaia zhivopis'. Stat'i i issledovaniia (Russian Medieval Painting. Articles and Studies). Moscow, Institut istorii iskusstv Ministerstva kul'tury SSSR, 1970, pp. 234-278.

19. Lazarev V. N. Murals of the Skovorodsky Monastery in Novgorod. Lazarev V. N. Russkaia srednevekovaia zhivopis'. Stat'i i issledovaniia (Russian Medieval Painting. Articles and Studies). Moscow, Institut istorii iskusstv Ministerstva kul'tury SSSR, 1970, pp. 216-233 (in Russian).

20. Lifshits L. I. Monumental'naia zhivopis' Novgoroda XIV-XV vv (Monumental Painting of Novgorod of the $14^{\text {th }}-15^{\text {th }}$ Centuries). Moscow, Iskusstvo Publ., 1987. 524 p. (in Russian).

21. Malkov Iu. G. Frescoes in the Church of the Nativity of Christ on the Cemetery. Khudozhestvennoe nasledie. Khranenie, issledovanie, restavratsiia (The Artistic Heritage. Preservation, Research, Restoration), 1978, vol. 4, pp. 193-221 (in Russian). 
22. Malkov Iu. G. About the Dating of Murals of the Archangel Mikhail 'na Skovorodke' in Novgorod. Drevnerusskoye iskusstvo XIV-XV vv. (Ancient Russian Art. $14^{\text {th }}-15^{\text {th }}$ Centuries). Moscow, Izdatel'stvo Akademii nauk SSSR Publ., 1984, pp. 196-225 (in Russian).

23. Malkov Iu. G. On the Role of the Balkan Artistic Tradition in the Russian Painting of the $14^{\text {th }}$ Century. Some Aspects of the Work of Theophanes the Greek. Drevnerusskoe iskusstvo. Monumental'naia zhivopis' XI-XVII vekov (Ancient Russian Art. $11^{\text {th }}-17^{\text {th }}$ Centuries). Moscow, Nauka Publ., 1980, pp. 135-160 (in Russian).

24. Manojlović-Radojčić Lj. Illustrated Calendar at Markov Manastir. Zbornik Matice Srpske za Likovne Umetnosti, 1973, vol. 9, pp. 61-80 (in Serbian).

25. Mavrodinova L. Zemenskata tsŭrkva. Istoriia, arkhitektura, zhivopis (The Church of Zemen, History, Architecture, Frescoes). Sofia, Bŭlgarski Chudozhnik Publ., 1980. 214 p. (in Bulgarian).

26. Migne J.-P. (ed.). Patrologiae cursus completus. Series graeca, vol. 100. Paris, Imprimerie Catholique Publ., 1865. 1544 cols. (in Greek and Latin).

27. Mirković L.; Tatić Ž. Markov manastir (Markov Monastery). Beograd, Grafika Publ., 1925. 76 p. (in Serbian).

28. Moshin V. The Life of the Elder Isaiah, Hegoumen of the Russian Monastery on Athos. Sbornik Russkogo Arkheologicheskogo obshchestva v Korolevstve Iugoslavii (The Collected Essays of the Russian Archaeological Society in the Kingdom of Jugoslavia), 1940, vol. 3, pp. 125-167 (in Russian).

29. Nemykina E. On the Problem of 'Southern Slavic Influence' on Novgorod Monumental Painting in the Second Half of the $14^{\text {th }}$ Century. Maltseva S. V.; Stanyukovich-Denisova E. Yu. (eds.). Actual Problems of Theory and History of Art: Collection of Articles, vol. 1. St. Petersburg, NP-Print Publ., 2011, pp. 109-114 (in Russian).

30. Nemykina E. The Composition 'Upon the Right Hand Did Stand the Queen' and the Hypothesis of the Novgorodian and Balkan Relations in the Mural Painting of the $14^{\text {th }}$ Century. Maltseva S. V.; Stanyukovich-Denisova E. Yu. (eds.). Actual Problems of Theory and History of Art: Collection of Articles, vol. 3. St. Petersburg, NP-Print Publ., 2013, pp. 186-194 (in Russian).

31. Papamastorakēs T. O diakosmos tou troulou ton naōn tēs palaiologeias periodou stē Valkanikē chersonēso kai tēn Kypro (The Decoration of the Dome of the Palaeologan Period Churches in the Balkan Peninsula and Cyprus). Athens, $\overline{\mathrm{E}}$ en Athēnais Archaiologikē Etaireia Publ., 2001. 564 p. (in Greek).

32. Prolović J. Die Kirche des Heiligen Andreas an der Treska. Wien, Österreichische Akademie der Wissenschaften Publ., 1997. 307 p. (in German).

33. Shapovalova A. N. The Novgorod Mural Paintings and Religious Theories of the East Christian World in the Second Half of the $14^{\text {th }}$ Century. Maltseva S. V.; Stanyukovich-Denisova E. Yu. (eds.). Actual Problems of Theory and History of Art: Collection of Articles, vol. 1. St. Petersburg, NP-Print Publ., 2011, pp. 115-123 (in Russian).

34. Shapovalova A. N. Rediscovering Frescoes of Archangel Michael Church in Skovorodsky Monastery of Novgorod the Great: Archival Documents and Field Research. Zakharova A. V.; Maltseva S. V. (eds.). Actual Problems of Theory and History of Art: Collection of Articles, vol. 4. St. Petersburg, NP-Print Publ., 2014, pp. 144-154 (in Russian).

35. Shapovalova A. N. Decoration of the Upper Part of the Church of Archangel Michael on Skovorodka: To the Problem of the Wall-Paintings Iconographic Programme. Novgorod i Novgorodskaia zemlia. Iskusstvo i restavratsiia, 6 (Novgorod and Novgorod Land. Art and Restoration, vol. 6). St. Petersburg, Pervyi Iph Publ., 2015, pp. 196-207 (in Russian).

36. Starodubcev T. The Image of the Virgin with Christ in the Niche on the Western Facade in the Church of the Transfiguration in Novgorod and the Question of the Origin of Her Painter. Zograf, 2010, vol. 34, pp. 137-152 (in Serbian).

37. Starodubcev T. Representation of the Heavenly Liturgy in the Dome. Maksimović Lj.; Radošević N.; Radulović E. (eds.). Treća jugoslovenska konferencija vizantologa (The Third Yugoslav Conference of Byzantinists). Beograd; Kruševac, Vizantološki institut SANU, Narodni muzej u Kruševcu Publ., 2002, pp. 381-411 (in Serbian).

38. Tomić Đurić M. To Picture and to Perform: The Image of the Eucharistic Liturgy at Markov Manastir (I). Zograf, 2015, vol. 39, pp. 129-150.

39. Trifunović Dj. Pisac i prevodilac Inok Isaija (Author and Translator Elder Isaija). Kruševac, Bagdala Publ., 1980. 110 p. (in Serbian). 
40. Trifunović Dj. Collections of Work of Pseudo-Dionysius the Areopagite Translated by Elder Isaija. Cyrillomethodianum, 1981, vol. 5, pp. 166-171.

41. Tsarevskaia T. Iu. The Fresco "The Virgin Hodegetria” in the Church of the Savior on Ilyin Street and Its Artistic Origins. Zograf, 2010, vol. 34, pp. 125-136 (in Russian).

42. Tsarevskaia T. Iu. Rospis' tserkvi Feodora Stratilata na Ruch'iu v Novgorode i ee mesto $v$ iskusstve Vizantii i Rusi vtoroi poloviny XIV veka (The Painting of the Church of Theodore Stratelates on the Creek in Novgorod and Its Place in the Art of Byzantium and Russia in the Second Half of the $14^{\text {th }}$ Century). Moscow, Severnyi palomnik Publ., 2007. 616 p. (in Russian).

43. Tsarevskaia T. I. Tserkov' Rozhdestva Khristova na Krasnom pole bliz Novgoroda (Church of the Nativity of Christ on the Red Field near Novgorod). Moscow, Severnyi palomnik Publ., 2002. 73 p. (in Russian).

44. Tsigaridas E. N. Les Fresques de 1' église Sainte-Catherine de Thessalonique. Medaković D.; Grozdanov C. (eds.). Na tragovima Vojislava J. Đurića (On the Traces of Vojislav J. Đurić). Beograd, SANU Publ., 2011, pp. 157-165 (in French).

45. Vidoeska B. (ed.). Markov manastir, Sveti Dimitrija. Crteži na freski (Markov Manastery. The Church of St. Demetrios. Drawings of the Frescoes). Skopje, Natsionalna ustanova - Konzervatorski centar Skopje Publ., 2012. 46 p. (in Macedonian).

46. Vvedenskaya N. The Church of St. Simeon the God-Receiver at the Zverin monastery in Novgorod, 2017. Available at: https://churchsimeon.wordpress.com (accessed 29 March 2019).

47. Vzdornov G. I. Volotovo. Freski tserkvi Uspeniia na Volotovom pole bliz Novgoroda (The Frescoes of the Church of the Assumption on the Volotovo Field near Novgorod). Moscow, Iskusstvo Publ., 1989. 343 p. (in Russian).

Название статьи. Монументальная живопись в государстве Мрнявчевичей и позднесредневековом Новгороде: параллели в иконографии и программах росписей.

Сведения об авторе. Томич Джурич Марка - Ph. D., научный сотрудник. Институт Балканских исследований, Сербская академия наук и искусств, Кнез Михаила 37/IV, Белград, Сербия, 11000. marka.tomic@gmail.com

Аннотация. В статье исследуются иконографические и программные параллели между ансамблями росписей в двух далеких друг от друга регионах - в государстве Мрнявчевичей на Балканах (1365-1395) и Новгороде конца XIV - XV в. В первой части статьи анализируются купольные программы в наиболее значимых постройках семьи Мрнявчевичей (церкви Св. Димитрия Маркова монастыря на Сушице близ Скопье, Св. Димитрия в Прилепе, Св. Андрея на Треске) и в шести новгородских храмах второй половины XIV в. (церкви Успения на Волотовом поле, Спаса Преображения на Ильине улице, Св. Феодора Стратилата на Ручью, Спаса на Ковалеве, Рождества на Красном поле и Архангела Михаила на Сковородке).

Во второй части статьи рассматриваются особенности циклов менология в Марковом монастыре (сентябрь - декабрь) и в церкви Св. Симеона Богоприимца (1467) в Зверине монастыре (сентябрь август). Между двумя циклами существуют очевидные различия во времени создания, иконографических и агиографических источниках, количестве изображений и расположении каждого из циклов. Тем не менее есть основания утверждать, что и сербский, и русский ансамбль следуют одной и той же логике. Оба относятся к восточнохристианской традиции иллюстрирования церковного календаря, для которой характерно сокращение изображений до единственного типа - портрета святого.

Ключевые слова: государство Мрнявчевичей; позднесредневековый Новгород; восточнохристианское искусство; византийская иконография; купольные программы; цикл менология.

Title. Monumental Painting in the Mrnjavčević State and Late Medieval Novgorod: Parallels in Program and Iconography.

Author. Tomić Djurić, Marka - Ph. D., research associate. Institute for Balkan Studies, Serbian Academy of Sciences and Arts, Knez Mihaila 37/IV, 11000 Belgrade, Serbia. marka.tomic@gmail.com

Abstract. The present paper aims to examine iconographic and programmatic parallels between the pictorial ensembles of the churches from two distant regions - the Mrnjavčević State in the Balkans (1365-1395) and Novgorod of the late $14^{\text {th }}$ and $15^{\text {th }}$ centuries. The first part of the paper focuses on the programs in domes of the most important endowments of the Mrnjavčević family members (St. Demetrios at Sušica near Skopje - Markov Manastir, St. Demetrios in Prilep, St. Andrew at River Treska) and six Novgorod churches of the second half of the $14^{\text {th }}$ century (the Assumption in the Volotovo Field, the Saviour- 
Transfiguration in Iliina Street, St. Theodore Stratelates 'on the Spring', the Holy Saviour in Kovaliovo, the Nativity on the Red Field and Archangel Michael Church in Skovorodsky Monastery).

The second part of the paper is concerned with the painted menologia at Markov Manastir (September through December) and in the church of St. Simeon the God-Receiver at the Zverin monastery (1467) (September through August). There are obvious differences between the two cycles in terms of their date, iconographic and textual sources, spatial layout, and the number of images included. It can be argued, nonetheless, that both cycles follow the same pictorial logic. They both belong to the same tradition of calendrical illustration in East Christian art, which is characterized by the reduction of the visual programme to only one type of image - the portrait of the commemorated saint.

Keywords: Mrnjavčević State; Late Medieval Novgorod; East Christian art; late fourteenth and fifteenth centuries; Byzantine iconography; programs of the domes; menologion cycle. 


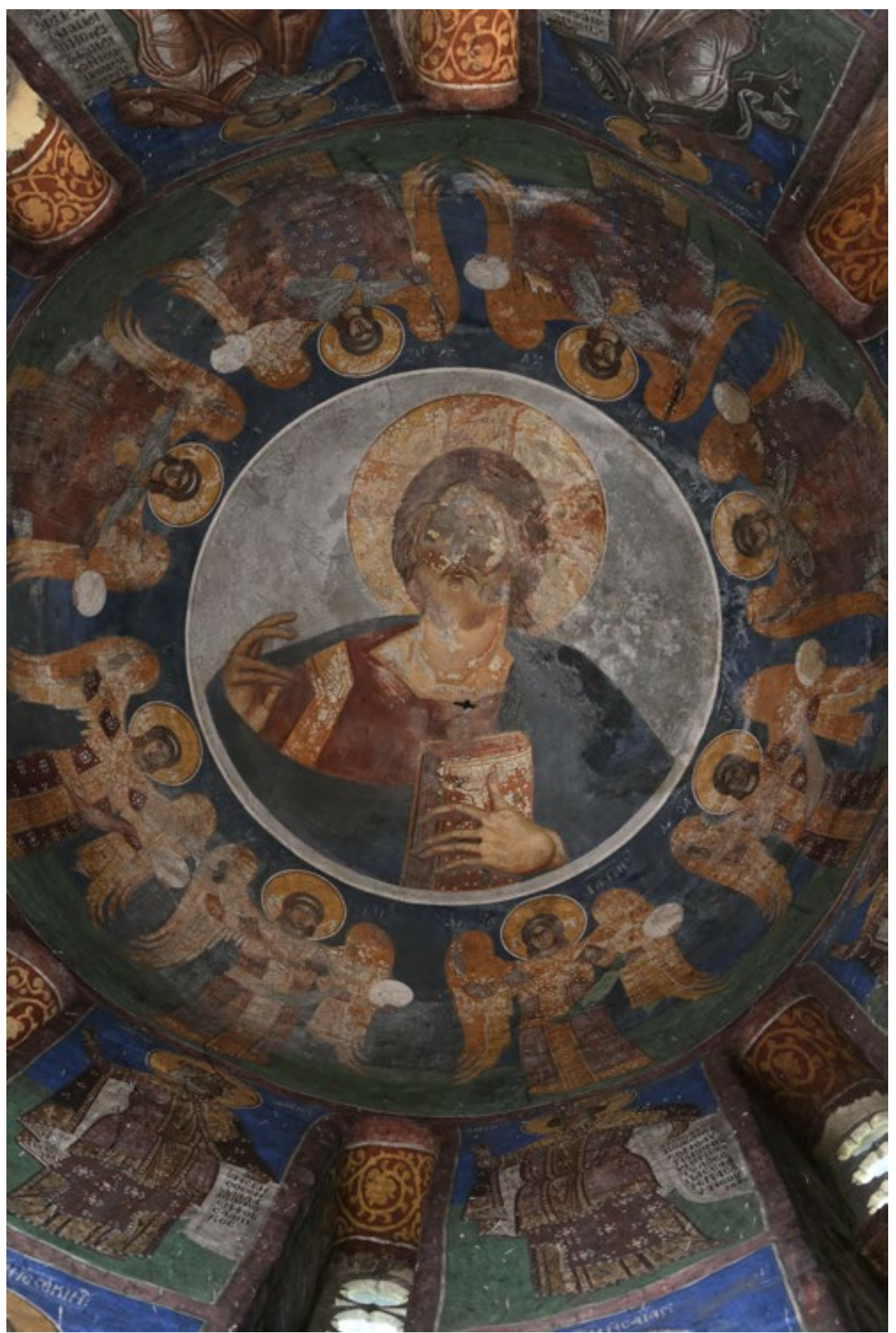

III. 60. Markov Manastir, The Church of St. Demetrios, 1376/1377. Frescoes in the dome. Photo by Dj. Djoković 


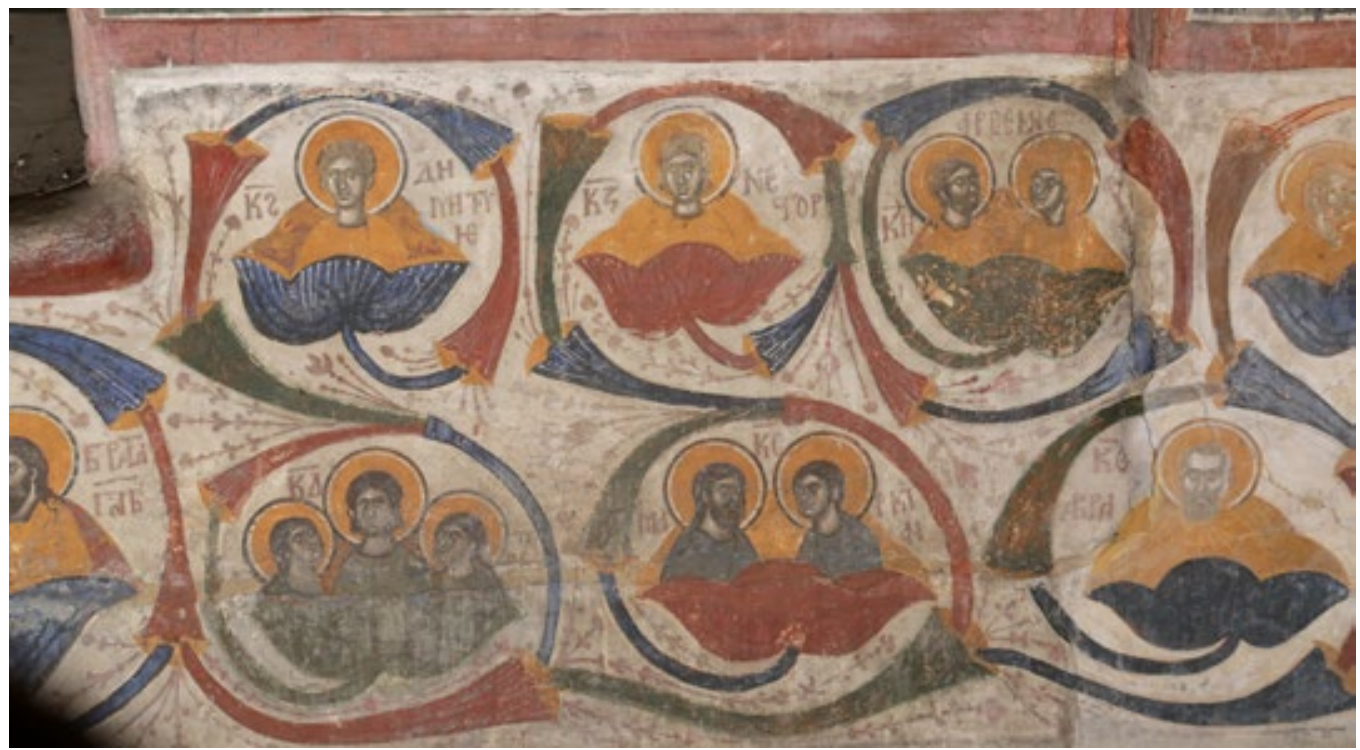

IIl. 61. Markov Manastir, The Church of St. Demetrios, 1376/1377. Menologion cycle, October. Photo by Dj. Djoković

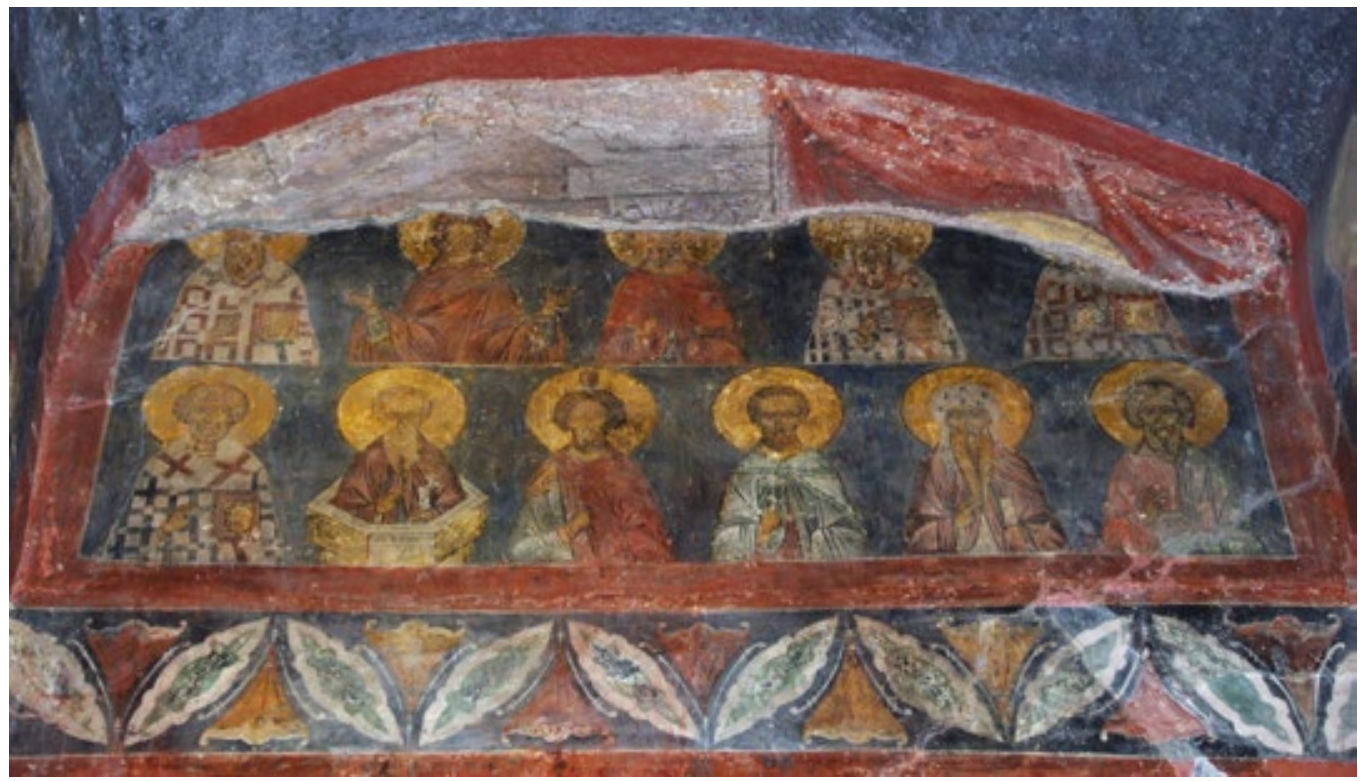

III. 62. Zverin monastery, The church of St. Simeon the God-Receiver, 1467. Menologion cycle, November. Photo by N. Vvedenska 